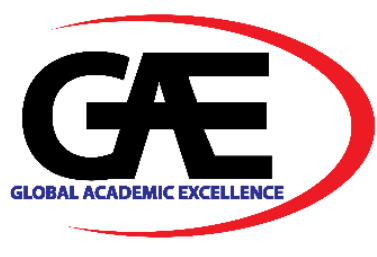

WWW.ijscol.com

\title{
SELF-EFFICACY BELIEFS IN AIR TRAFFIC MANAGEMENT SETTING
}

\author{
Shafazawana Mohamed Tharikh ${ }^{1 *}$, Siti Raba'ah Hamzah ${ }^{2}$, Nasrudin Baidi ${ }^{3}$, Jegatheesan Rajadurai ${ }^{4}$
}

1 College of Business Management and Accounting, University Tenaga Nasional, Malaysia

Email: shafa@uniten.edu.my

2 Faculty of Education, University Putra Malaysia, Malaysia

Email: sitirabaahhamzah@gmail.com

3 College of Business Management and Accounting, University Tenaga Nasional, Malaysia

Email: nasrudin@uniten.edu.my

4 College of Business Management and Accounting, University Tenaga Nasional, Malaysia

Email: jegatheesan@uniten.edu.my

Corresponding Author

\section{Article Info:}

\section{Article history:}

Received date: 19.08 .2020

Revised date: 17.09 .2020

Accepted date: 16.02 .2021

Published date: 01.03.2021

\section{To cite this document:}

Tharikh, S. M., Hamzah, S. R., Baidi, N., \& Rajadurai, J. (2021). SelfEfficacy Beliefs in Air Traffic Management Setting. International Journal of Supply Chain, Operation Management and Logistics, 2 (3), 1122.

DOI: $10.35631 /$ IJSCOL.23002

This work is licensed under $\underline{\text { CC BY } 4.0}$

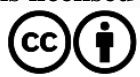

\begin{abstract}
:
Employee wellbeing is related to the daily work and life experience of all employees which should be seriously viewed by the managers to prepare employees to face head-on on new ways of working due to the change in the work environment. Concentrating on individual development has long-term benefits for the individual, organization, and society but yet the individual is frequently overlooked by organizations. Self-efficacy is a belief that someone can perform successfully. When the self-efficacy of employees is high, the employees can work independently and efficiently. Characteristics of high selfefficacy can be characterized as a person that would take a new challenge is something positive and do not easily give up (initiative), keep trying (effort), and prepared all the time for any problems in the future (persistence). A quantitative approach with cross-sectional design as a survey method has been employed in this study and purposive sampling was used as the sampling technique. A total of 209 usable questionnaires were processed in this study. Partial Least Square-Structural Equation Modelling (PLS-SEM) was used to validate the research model and to test the hypotheses. The Air Traffic Management sector is the largest sector in the Civil Aviation Authority of Malaysia (CAAM) and the primary job responsibility of Air Traffic Controllers (ATCs) is to control and navigate the movement of planes especially during take-off and landing. The job characteristics are distinct, and it leads ATCs to be stressful and demanding job. This study found that self-efficacy is related to employee wellbeing. ATCs with high self-efficacy produce good initiatives,
\end{abstract}


Keywords:

Self-Efficacy, Employee Wellbeing, Air Traffic Controllers

\section{Introduction}

Employees that have positive feelings and positive functioning are considered as employees who have good mental health (Keyes, 2002; Page \& Vella-Brodrick, 2009). Employees with high level of wellbeing are enthusiastic towards their work and will contribute more ideas and exertion into their work (Keeman et al., 2017). Recently, concerns in employee wellbeing has increased and it is a critical factor for individuals and organizations performance, and it encompasses a much broader concern to the employees (Clarke \& Hill, 2012; Wang \& Wang, 2016). It should be given important considerations by employers especially by top management because it will improve employees' happiness, and also their roles' satisfactions (Burns \& Machin, 2013; Zakaria et al., 2014). Employee wellbeing is related to the daily work and life experience of all employees which should be seriously viewed by the managers to prepare employees to face head-on on new ways of working due to the change in the work environment.

Generally, self-efficacy can be defined as the beliefs in one's own capabilities, their level of motivation and actions to take in many circumstances (Bandura, 1986). Self-efficacy is shaped since adolescence and developed with age subsequent to experiencing an assortment of circumstances, experiences, aptitudes, comprehension and assignments (Xanthopoulou et al., 2009). Self-efficacy will develop every time when a task is successfully accomplished and it will affect decisively on the attitude, behaviour's control, and inspiration to be succeed (Ishak, Mahfar \& Yusuf, 2016; Nielsen et al., 2009).

At the workplace, self-efficacy can be viewed as a cognitive component that influence someone's action such as influencing feelings, thinking and ability in executing and managing task effectively and efficiently. Self-efficacy has an impact on problem solving and decision making on challenging tasks (Ishak, Mahfar \& Yusuf, 2016). Future career performance is strongly related to employee's self-efficacy, including their ability to perform well in any given circumstances or experience (Nielsen et al., 2009; Souza et al., 2014; Yap \& Baharudin, 2016). Self-efficacy can play as a corrective action role such as on job burnout and job performance (Chen, Gully \& Eden, 2001). How individuals interpret their proficiencies and competences are revealed in their life fulfillment (Azizli et al., 2015). Souza et al. (2014) stated that high self-efficacy helps to resist over processes of stress, to increase individual's self-esteem, to increase general health and to live for a better wellbeing.

The air traffic management sector is the largest sector in the Civil Aviation Authority of Malaysia (CAAM). The aviation industry has strong impact towards other industries (Mahzan \& Abidin, 2015; Moon, Yoo \& Choi, 2000) especially in developing countries such as Malaysia. It is a very complex technology-centric industry which needs highly specialized skilled employees (Kuo, Jou, \& Lin, 2012; Teperi, Leppänen, \& Norros, 2015) to work in a fast pace innovative technology environment which is constantly changing like air traffic controllers' (ATCs) job. The primary job responsibility of ATCs is to control and navigate the movement of planes especially during take-off and landing (Juo \& Lin, 2012; Kontogiannis \& Malakis, 2013; Tobaruela et al., 2014). The researchers further explained that the job demands of ATCs require a high level of awareness and concentration as they need to carry out various 


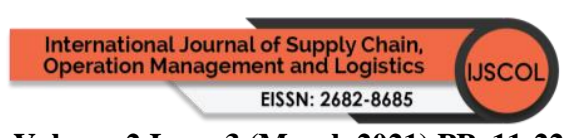

Volume 2 Issue 3 (March 2021) PP. 11-22

DOI 10.35631/IJSCOL.23002

functions at the same time, such as, thinking, listening and speaking. The job characteristics are distinct, and it leads ATC to be a stressful and demanding job (De Beer \& Tshabalala, 2011).

The volume of air traffic in Malaysia has grown tremendously due to the increase in the demand for air travel from 6.5\% to $11.8 \%$ year-on-year for its Malaysian operations (Malaysia Airports Holdings Bhd. (MAHB), 2017) and the development of air cargo hub such as the KLIA aeropolis could contribute to the congested airspace and will become more complex to manage by the ATCs (Juo, Kuo \& Tang, 2013; Tomic \& Liu, 2017). When the complexity of the aviation industry increases, ATCs can become overwhelmed with traffic and it will affect their behavior in performing their work (Tobaruela et al., 2014; Tomic \& Liu, 2017; Yang \& Dattel, 2017).

In this sense, considering the importance of self-efficacy beliefs among ATCs, this study seeks to explain the gap on the relationship between self-efficacy and employee wellbeing among ATCs based on the Malaysian context.

\section{Literature Review}

\section{Employee Wellbeing}

Generally, wellbeing is a continuous range of positive emotions and subjective life evaluations for every individual. It is generally utilized conversely with bliss (Bartels, 2015; YoussefMorgan \& Luthans, 2015). Wellbeing takes shape under the action of a few elements associated with the various phases of individual presence (Lilianna \& Nicoleta, 2014). Various studies (e.g. Bartels, 2015; Burns \& Ma, 2015; Keeman et al., 2017; Sonnentag, 2015) have followed the philosophical traditions of two distinctive viewpoints which are basically different. The two traditions are mostly utilized in studies that make up these conventions namely hedonic or also known as subjective wellbeing which does reflect someone happiness and the psychological wellbeing that is referring to human potential which is also known as eudemonic (Brown \& Ryan, 2003; Burns \& Ma, 2015; Keyes, Smothkin \& Ryff, 2002).

In order to carry out a reasonable and substantial assessment, it is logically quite basic to perceive what is assessed for employee wellbeing and how the results should be deciphered (Dodge et al., 2012). Clearly, most organizations need to achieve their execution (Zakaria et al., 2014). However, there are various factors focusing on execution, such as, the employees' wellbeing, should not be dismissed and attention should keep on being paid on it (Duygulu et al., 2013; Juniper et al., 2011; Slemp \& Vella-Brodrick, 2013).

Wellbeing relationships in the workplace would be reinforced notwithstanding subjective wellbeing and psychological wellbeing (Page \& Vella-Brodrick, 2009; Plomp et al., 2016; Warr, 2011). They proposed work - related effects and occupation satisfaction, or called workplace wellbeing, which is evaluated while examining the employee wellbeing. In the other word, employees generally feel great in the organizations when their organization focuses on individual workers.

\section{Self-Efficacy}

Self-efficacy can be defined as a belief that someone can perform successfully (Sadri \& Robertson, 1993). Empirical studies perceived that self-efficacy at workplace can boost the motivation of employees to achieve the organizational goals (Bandura, 1989; Cherian \& Jacob, 


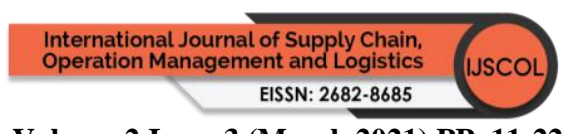

Volume 2 Issue 3 (March 2021) PP. 11-22

DOI 10.35631/IJSCOL.23002

2013) as when the self-efficacy of employees is high, the employees can work independently and efficiently (Ishak et al., 2016), will be able to overcome pressure and can demonstrate high sense of commitment to complete challenging tasks (Gkolia, Belias \& Koustelios., 2014), help to reduce job burnout among employees (Capone, Joshanloo \& Park, 2019) and increase employee job performance (Na-nan \& Sanamthong, 2019).

The connection between self-efficacy and employee wellbeing is reliably associated in deciding the potential and execution of an errand (Greguras et al., 2014). An exploration on proficient salespeople has supported this relationship and indicated that employees who are tireless and productive are equipped for doing their obligations and accomplish work fulfilment in their work appropriately (Ishak et al., 2016). The adequacy of self-efficacy on employee wellbeing will increase if the employer is able to encounter the employees' needs and issues (Consiglio et al., 2016).

A review and meta-analysis study which was exclusively conducted by Sadri and Robertson (1993) in United States and United Kingdom found that self-efficacy has positive relationship between work-related behaviors. The link between self-efficacy and employee wellbeing dependably corresponded in determining the potential and performance of a task (LaMuth, 2006). Whilst general self-efficacy (persistence, initiative and effort) is positively related to the employees' job performance (Judge \& Bono, 2001) and employee innovation performance (Mumtaz \& Parahoo, 2019).

Consiglio et al. (2016) in their three-year study of 741 employees at a communication service company found that work engagement relied upon the self-efficacy of employees. This study is aligned with Bakker (2011) which reviewed articles and then found that employees who are occupied with their work are completely associated with their work roles. Work engagement is predicted by job resources and personal resources (e.g. self-efficacy) and leads to higher occupation execution (Bakker, 2011). In other settings of a study led by Maujean and Davies (2013) claimed that self-efficacy in psychosocial and physical functioning was related to wellbeing. They found that self-efficacy does influence stroke survivor's wellbeing.

Other study demonstrated that the development of children's self-efficacy is formed since childhood and grew with age after going through various situation and circumstances (LaMuth, 2006). It is important for parental influence to develop child self-efficacy (Santos et al., 2014). Both studies found that child's self-efficacy is related to their wellbeing. Study on general selfefficacy has been conducted among Canadian university students (Azizli et al., 2015), Filipino college students (Santos et al., 2014) and American undergraduates' students (Soysa \& Wilcomb, 2015), and all findings revealed that, students with high self-efficacy will contribute to high wellbeing.

Canadian teachers' self-efficacy is found to be related to their wellbeing, since they tend to be more persistent, utilize class time, less criticizing students, students' autonomy is encouraged and responsibility, and patient in handling challenging students by planning various ideas to reduce the problem students' wellbeing (Wang, Hall \& Rahimi, 2015). While in Hong Kong, 1115 primary school teachers revealed that self-efficacy is positively related to their wellbeing when they are given trust by the school management (Huang, Yin \& Lv, 2019).

Self-efficacy will increase every time when the individuals manage to complete their tasks (Ishak et al., 2016), experience in facing or solving problem in challenging tasks (Homa et al., 


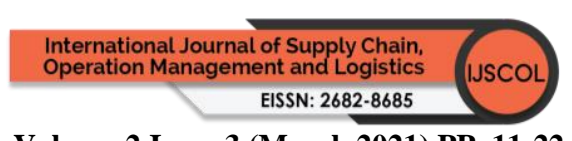

Volume 2 Issue 3 (March 2021) PP. 11-22

DOI 10.35631/IJSCOL.23002

2014) and if employers are able to meet the needs of employees (Orozco, 2010). Self-efficacy is strongly related to employee's future directions such as career performance (Ishak et al., 2016) and employee engagement (Bakker, 2011), thus self-efficacy is hoped to have positive relationship with employee wellbeing among ATCs in their career development and organizational development. A mismatch between self-efficacy and performance domain (Stajkovic \& Luthans, 1998) will lead to poor employee wellbeing. Self-efficacy determines whether a person's adapting behavior will be initiated, how much task-related effort will be expended or persistence, and to what extent that effort will be supported regardless of disconfirming proof (Stajkovic \& Luthans, 1998). Hence the following hypotheses are developed:

Hypothesis 1 (H1): Self-efficacy has a significant relationship with employee wellbeing Hypothesis 1a (H1a): Initiative significantly influence employee wellbeing

Hypothesis 1b (H1b): Effort significantly influence employee wellbeing

Hypothesis 1c (H1c): Persistence has a significant relationship with employee wellbeing

\section{Methodology}

A quantitative approach with cross-sectional design as a survey method has been employed in this study and purposive sampling was used as the sampling technique.

\section{Respondents}

A total of 248 questionnaires were distributed to the targeted respondents in Region 1 Peninsular Malaysia. The number of questionnaires returned was 209 which was 84.3 percent of response rate. In this study, $134(64.1 \%)$ of the respondents were male and $75(35.9 \%)$ female. Ages ranged between 23 - 36 years were 115 (55\%), while 37-52 years and 53 years and above were $77(36.8 \%)$ and $17(8.1 \%)$ respectively. The number of married ATCs were 178 , which was $85.2 \%$ more than single ATCs with only $31(14.8 \%)$ of them. On ethnicity, the majority among ATCs at both airports were Malay with $176(84.2 \%)$ of them, followed by 16 Indian (7.7\%), 10 Chinese (4.8\%) and 7 others (3.3\%). In terms of experience, most of ATCs had 1-10 years of experience represented by $121(57.9 \%)$ respondents, those with experience ranging between 11-20 years were represented by $52(24.9 \%)$ respondents. Next, $20(9.6 \%)$ ATCs had 21 - 30 years' experience and finally, $16(7.7 \%)$ ATCs were among employees that have experience ranging from 31 - 40 years.

\section{Questionnaires}

The procedure done in developing the survey instrument for this study consists of: (i) construct conceptualization, (ii) general items to represent the construct, (iii) assessment of the face and content validity of the items, (iv) scale evaluation and refinement and, (v) validation.

\section{Self-Efficacy}

In this study, General Self-Efficacy Scale has been adapted to measure the self-efficacy among ATCs because this scale is convenient for boosting employee wellbeing which is aligned with the objectives of this study to capture the individuals' tendency to view the individual's capability in performing their task demand in a broad array of context (Chen, Gully \& Eden, 2001). The scale is comprised 17 questions of initiative, effort and persistence.

\section{Employee Wellbeing}

By reverberating the discoveries above in literature, and taking the orderly viewpoint, this present study consolidates subjective wellbeing, psychological wellbeing and workplace 


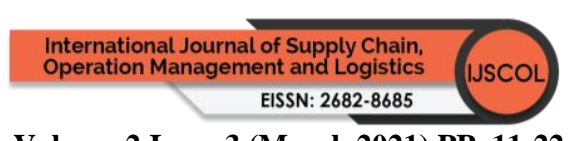

Volume 2 Issue 3 (March 2021) PP. 11-22

DOI 10.35631/IJSCOL.23002

wellbeing into employee wellbeing. Flourishing scale with eight questions were adopted by Diener et al. (2009) which represented as the psychological wellbeing while 12 questions with six items devoted to positive encounters and six items intended to assess negative experiences were adopted by Diener et al. (2009) which represented as subjective wellbeing. In view of the general items incorporated into the scale, it can assess not only the pleasant and unpleasant emotional feelings that are the focal point of most scales, yet in addition reflects different states like interest, stream, positive commitment, and physical pleasure (Diener et al., 2009). Nineitems with four components; work satisfaction, respect from the employees, employer care and intrusion of workers' private life, represented workplace wellbeing was adapted by Hyett and Parker (2015).

\section{Data Analysis}

\section{Validity}

The construct validity was examined by assessing the cross loading and factor loading. From Table 1, it was observed that all the items measuring a particular variable were greater than 0.50 on those variables, thus confirming construct validity. Previous researchers suggest that the cut-off value for factor loadings should equal to and exceed 0.50 are acceptable, if the summation of loading results in high loading scores, contributing to AVE scores of greater than 0.5 (Byrne, 2013). Following these criteria, items with factor loading less than 0.50 were deleted. After removing seven items which less than the recommended value, all measurement items range from 0.516 to 0.912 .

Convergent validity is sufficient when variables have an AVE minimum value of 0.5 or more (Hair et al., 2013). Table 1 shows that all variables in measurement model for this study had AVE ranging from 0.501 to 0.794 , which exceeded the suggested threshold value of 0.5 . This result showed that the study's measurement model verified an adequate convergent validity.

\section{Reliability}

A measurement model has acceptable internal consistency reliability when the composite reliability (CR) of every variable surpasses the edge value of 0.7 . Table 1 show that the CR of every variable for this study ranges from 0.92 to 0.958 and this was over the suggested threshold value of 0.7 . Hence, the results demonstrated that the items used to represent the variables had satisfactory internal consistency reliability.

\begin{tabular}{lcc} 
Table 1: Composite Reliability (CR) and Average & $\begin{array}{c}\text { Variance Extracted (AVE) } \\
\text { Composite } \\
\text { Reliability (CR) }\end{array}$ & $\begin{array}{c}\text { Average Variance } \\
\text { Extracted (AVE) }\end{array}$ \\
\hline Effort & 0.946 & 0.639 \\
Employee Wellbeing & 0.958 & 0.501 \\
Initiative & 0.920 & 0.794 \\
Persistence & 0.923 & 0.751 \\
\hline
\end{tabular}

Fornell and Larcker's (1981) paradigm was utilized in this study, to survey the measurement model's discriminant validity. Table 2 shows the result of measurement model's discriminant validity by utilizing Fornell and Larcker's measure. In light of the outcomes, all square roots of AVE exceeded the off-diagonal components in their relating row and column. The bolded components in Table 2 represent the square roots of the AVE, and non-bolded values represent 


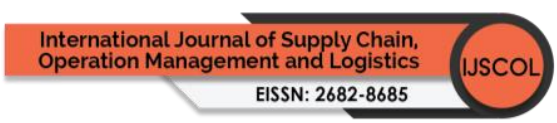

Volume 2 Issue 3 (March 2021) PP. 11-22

DOI 10.35631/IJSCOL.23002

the inter-correlation value between variables. All off-diagonal components are lower than square roots of AVE (bolded on the diagonal). Subsequently, the outcome affirmed that the Fornell and Larker's measure was met. This study, therefore, presumes that the measurement model had set up its discriminant validity.

Table 2: Fornell and Larcker Criterion

\begin{tabular}{lrrrr}
\hline & Effort & $\begin{array}{l}\text { Employee } \\
\text { Wellbeing }\end{array}$ & Initiative & Persistence \\
\hline Effort & $\mathbf{0 . 7 9 9}$ & & & \\
Employee Wellbeing & 0.632 & $\mathbf{0 . 7 0 3}$ & & \\
Initiative & 0.473 & 0.316 & $\mathbf{0 . 8 9 1}$ & \\
Persistence & 0.303 & 0.275 & 0.404 & $\mathbf{0 . 8 6 7}$ \\
\hline
\end{tabular}

Table 3 shows that first hypothesis (H1a) which was the relationship of effort and employee wellbeing indicated that the relationship was statistically significant with t-value 8.523 with pvalue $<0.01$. The second hypothesis $(\mathrm{H} 1 \mathrm{~b})$ studied on the relationship between imitative and employee wellbeing which showed t-value 2.923 with $\mathrm{p}$-value $<0.01$. The next hypothesis (H1c) represented the relationship between persistence and employee wellbeing and the result present the t-value 2.179 with $\mathrm{p}$-value $<0.01$. Based on output of the $\mathrm{t}$-value, hypothesis 1 a to hypothesis 1c were accepted.

Table 3: Result of Bootstrapping Analysis (Direct Effect)

\begin{tabular}{|c|c|c|c|c|}
\hline Hypotheses & Path & $\begin{array}{l}\text { Standard } \\
\text { Deviation }\end{array}$ & T Value & Decision \\
\hline $\begin{array}{l}\text { H1a: Effort } \rightarrow \text { Employee } \\
\text { Wellbeing }\end{array}$ & 0.608 & 0.071 & $8.523 * *$ & Accepted \\
\hline $\begin{array}{l}\text { H1b: Initiative-> Employee } \\
\text { wellbeing }\end{array}$ & 0.528 & 0.087 & $2.923 * *$ & Accepted \\
\hline $\begin{array}{l}\text { H1c: Persistence-> Employee } \\
\text { wellbeing }\end{array}$ & 0.452 & 0.080 & $2.179 * *$ & Accepted \\
\hline
\end{tabular}

Note: $\mathrm{t}$-value more than $1.64^{*}$ at $\mathrm{p}<0.05$, $\mathrm{t}$-value more than $2.33^{* *}$ at $\mathrm{p}<0.01$

\section{Discussion of Findings}

In the study by Cherian and Jacob (2013) and also by Judge and Bono (2001) found that wellbeing of employees is positively influenced by self-efficacy. Employee wellbeing differs from occupation to occupation. Self-efficacy became one of the important elements to boost employee motivation to improve their wellbeing at the workplace.

ATCs with high self-efficacy produces good initiatives, effort and persistence in doing their job. Characteristics of high self-efficacy can be characterized as a person that would take new challenge is something positive and do not easily give up (initiative), keep trying (effort) and prepared all the time for any problems in the future (persistence) (Azizli et al., 2015). In this study, ATCs' self-efficacy is found to be related to their wellbeing, where they tend to be more persistent in utilizing their time on duty, effort from leaders' and employees' autonomy are 


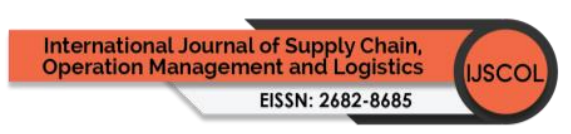

Volume 2 Issue 3 (March 2021) PP. 11-22

DOI 10.35631/IJSCOL.23002

encouraged, being responsible and patient in handling increasing traffic demand by planning various ideas to reduce the problem among them. This finding is aligned with study conducted by Wang, Hall and Rahimi (2015) and Pisanti et al. (2015) which stated that employees with high self-efficacy will have passion in their behavior characteristics by ensuring their effort, initiatives and persistence in any future circumstances.

Self-efficacy is a dynamic construct that could change over time and depends on someone's experience (Mumtaz \& Parahoo, 2019). Therefore, organizations that can initiate supportive programs for their employees will earn strong self-efficacy because the knowledge is continually being updated and shared. Further, the researchers added that by providing regular, relevant, balanced feedback improves self-efficacy of individuals.

\section{Future Recommendations}

Future research should also attempt to replicate the present study, to bring the study of employee wellbeing beyond the workplace or in different settings such as students' wellbeing at the universities. Empirical studies on wellbeing especially on employee wellbeing are limited in Malaysia. However, there may be other factors that can be suggested to study among ATCs besides self-efficacy and employee wellbeing it is also recommended to study work environment, leadership styles and human resource management towards employee wellbeing. Employee wellbeing ought not to be exclusively be concerned with mental disorders yet additionally ought to effectively advance in promoting mental health and resilience.

\section{Conclusion}

ATCs have enduring initiative, effort and persistence to solve their obstacles and challenges at work to sustain their wellbeing. They manage their feelings well, self-acknowledgment hindrances and how to construct positive association with their job, colleagues and the management. They are competent in dealing with their emotions, self-acknowledgment hindrances resulting in positive connectedness with their job, colleagues and the management. It allows opportunities for self-improvement and advancement, capitalizing on the good experience of self for a central social role that permits interest in interpersonal organizations beyond primary groups.

ATCs are aware of their job responsibilities before they choose to accept this profession as their career. They should prepare themselves to gain high self-efficacy, so that, they will remain in the field for whatever hindrances that may come.

\section{References}

Azizli, N., Atkinson, B. E., Baughman, H. M., \& Giammarco, E. A. (2015). Relationships between general self-efficacy, planning for the future, and life satisfaction. Personality and Individual Differences, 82, 58-60.

Byrne, B. M. (2013). Structural equation modeling with Mplus: Basic concepts, applications, and programming. Routledge.

Bakker, A. B. (2011). An evidence-based model of work engagement. Current directions in psychological science, 20(4), 265-269.

Bandura, A. (1986). The explanatory and predictive scope of self-efficacy theory. Journal of social and clinical psychology, 4(3), 359-373.

Bandura, A. (1989). Regulation of cognitive processes through perceived selfefficacy. Developmental psychology, 25(5), 729. 


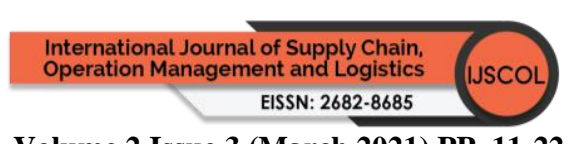

Volume 2 Issue 3 (March 2021) PP. 11-22

DOI 10.35631/IJSCOL.23002

Bartels, M. (2015). Genetics of Wellbeing and Its Components Satisfaction with Life, Happiness, and Quality of Life: A Review and Meta-analysis of Heritability Studies. Springerlink.com, 45, 137-156.

Brown, K. W., \& Ryan, R. M. (2003). The benefits of being present: mindfulness and its role in psychological well-being. Journal of personality and social psychology, 84(4), 822.

Burns, R. A., \& Ma, J. (2015). Examining the association between psychological wellbeing with daily and intra-individual variation in subjective wellbeing. Personality and Individual Differences, 82, 34-39.

Burns, R. A., \& Machin, M. A. (2013). Psychological wellbeing and the diathesis-stress hypothesis model: The role of psychological functioning and quality of relations in promoting subjective well-being in a life events study. Personality and Individual Differences, 54(3), 321-326.

Capone, V., Joshanloo, M., \& Park, M. S. A. (2019). Burnout, depression, efficacy beliefs, and work-related variables among school teachers. International Journal of Educational Research, 95, 97-108.

Chan, S. C. (2014). Paternalistic leadership and employee voice: Does information sharing. (2001). Validation of a new general self-efficacy scale. Organizational research methods, 4(1), 62-83.

Cherian, J., \& Jacob, J. (2013). Impact of Self Efficacy on Motivation and Performance of Employees. International Journal of Business and Management, 8(14), 80-88.

Clarke, M. A., \& Hill, S. R. (2012). Promoting employee wellbeing and quality service outcomes: The role of HRM practices. Journal of Management \& Organization, 18(5), $702-713$.

Consiglio, C., Borgogni, L., Di Tecco, C., \& Schaufeli, W. B. (2016). What makes employees engaged with their work? The role of self-efficacy and employee's perceptions of social context over time. Career Development International, 21(2), 125-143.

De Beer, M., \& Tshabalala, M. (2014). Occupational stress and coping resources in air traffic control. Ergonomics SA: Journal of the Ergonomics Society of South Africa, 26(1), 3143.

Diener, E., Lucas, R. E., \& Scollon, C. N. (2009). Beyond the hedonic treadmill: Revising the adaptation theory of well-being. In The science of well-being (pp. 103-118). Springer, Dordrecht.

Dodge, R., Daly, A. P., Huyton, J., \& Sanders, L. D. (2012). The challenge of defining wellbeing. International journal of wellbeing, 2(3).

Duygulu, E., Ciraklar, N. H., Guripek, E., \& Bagiran, D. (2013). The effect of role stress on the employee's well-being: a study in the pharmaceutical companies in the city of Izmir. Procedia-Social and Behavioral Sciences, 84, 1361-1368.

Fornell, C., \& Larcker, D. F. (1981). Structural equation models with unobservable variables and measurement error: Algebra and statistics.

Gkolia, A., Belias, D., \& Koustelios, A. (2014). Teacher's job satisfaction and selfefficacy: A review. European Scientific Journal, ESJ, 10(22).

Greguras, G. J., Diefendorff, J. M., Carpenter, J., \& Tröster, C. (2014). Personenvironment fit and self-determination theory. 2014, 143-61.

Hair, J. F., Hult, G. T. M., Ringle, C. M., \& Sarstedt, M. (2013). A Primer on Partial Least Squares Structural Equation Modeling (PLS-SEM). Thousand Oaks: Sage.

Homa Khorasani Esmaeili, Hamed Tahsildari, Mohd Taib Hashim \& Rosmini Omar (2014). The Concurrent Role of Personality Traits and Self-Efficacy on Employees' Work Satisfaction: A Review. Interdisciplinary Journal Of Contemporary Research In Business, 5, 11. 


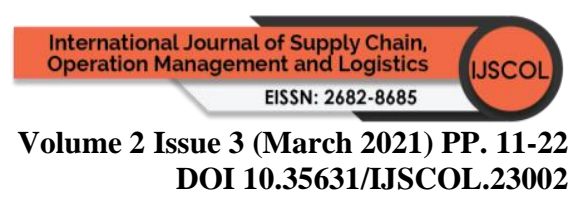

Huang, S., Yin, H., \& Lv, L. (2019). Job characteristics and teacher well-being: the mediation of teacher self-monitoring and teacher self-efficacy. Educational Psychology, 39(3), 313-331.

Hyett, M. P., \& Parker, G. B. (2015). Further examination of the properties of the workplace well-being questionnaire (WWQ). Social Indicators Research, 124(2), 683-692.

Ishak, A., Mahfar, M., \& Yusof, H. M. (2016). Sains Humanika A Review of Impact of Personality Big Five, Self-Efficacy and Autonomy on Job Satisfaction Among Employees., 1(2013), 13-21.

Jou, R. C., Kuo, C. W., \& Tang, M. L. (2013). A study of job stress and turnover tendency among air traffic controllers: The mediating effects of job satisfaction. Transportation research part E: logistics and transportation review, 57, 95-104.

Judge, T. A., \& Bono, J. E. (2001). Relationship of core self-evaluations traits-self-esteem, generalized self-efficacy, locus of control, and emotional stability-with job satisfaction and job performance: A meta-analysis. Journal of applied Psychology, 86(1), 80.

Juniper, B., Bellamy, P., \& White, N. (2011). Testing the performance of a new approach to measuring employee well-being. Leadership \& Organization Development Journal, 32(4), 344-357.

Keeman, A., Näswall, K., Malinen, S., \& Kuntz, J. (2017). Employee wellbeing: evaluating a wellbeing intervention in two settings. Frontiers in psychology, 8, 505.

Keyes, C. L. (2002). The mental health continuum: From languishing to flourishing in life. Journal of health and social behavior, 207-222.

Kontogiannis, T., \& Malakis, S. (2013). Strategies in coping with complexity: Development of a behavioural marker system for air traffic controllers. Safety science, 57, 27-34.

Kuo, C. W., Jou, R. C., \& Lin, S. W. (2012). Turnover intention of air traffic controllers in Taiwan: A note. Journal of Air Transport Management, 25, 50-52.

LaMuth, J. E. (2006). A comparison of formal and non-formal managers within Ohio State University Extension: An examination of self-efficacy, training choices, and job satisfaction (Doctoral dissertation, The Ohio State University).

Mahzan, N., \& Abidin, A. Z. Z. (2015). Examining Navigators' Job Satisfaction in Royal Malaysian Air Force through the Lenses of Herzberg's Motivation-Hygiene Theory. Journal of Economics, Business and Management, 3(8), 758-762.

Maujean, A., \& Davis, P. (2013). The relationship between self-efficacy and well-being in stroke survivors. International Journal of Physical Medicine \& Rehabilitation, 4, 1-10.

Moon, W. C., Yoo, K. E., \& Choi, Y. C. (2011). Air traffic volume and air traffic control human errors. Journal of Transportation Technologies, 1(03), 47.

Mumtaz, S., \& Parahoo, S. K. (2019). Promoting employee innovation performance: Examining the role of self-efficacy and growth need strength. International Journal of Productivity and Performance Management.

Na-Nan, K., \& Sanamthong, E. (2019). Self-efficacy and employee job performance. International Journal of Quality \& Reliability Management.

Nielsen, K., Yarker, J., Randall, R., \& Munir, F. (2009). The mediating effects of team and self-efficacy on the relationship between transformational leadership, and job satisfaction and psychological well-being in healthcare professionals: A cross-sectional questionnaire survey. International journal of nursing studies, 46(9), 1236-1244

Orozco, L. M. (2010). An Empirical Comparison between the NEO-FFI and the WPI and the Relationship between Self-Efficacy and Workplace Personality. Texas A\&M University. 


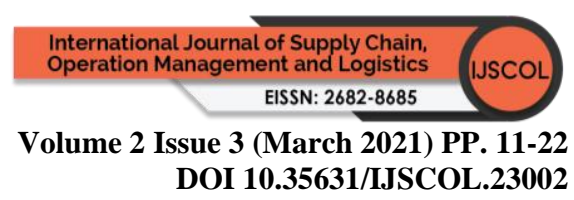

Page, K. M., \& Vella-Brodrick, D. A. (2009). The "what", "why" and "how" of employee wellbeing: A new model. Social Indicators Research, 90(3), 441-458.

Pisanti, R., van der Doef, M., Maes, S., Lombardo, C., Lazzari, D., \& Violani, C. (2015). Occupational coping self-efficacy explains distress and well-being in nurses beyond psychosocial job characteristics. Frontiers in psychology, 6, 1143.

Plomp, J., Tims, M., Akkermans, J., Khapova, S. N., Jansen, P. G., \& Bakker, A. B. (2016). Career competencies and job crafting: How proactive employees influence their wellbeing. Career Development International, 21(6), 587-602.

Sadri, G., \& Robertson, I. T. (1993). Self-efficacy and work-related behaviour: a review and meta-analysis. Applied Psychology, 42(2), 139-152.

Sanda, M. A. (2018). Relevance of air-traffic controllers' tacit knowledge in enhancing airtraffic control and safety in Ghanaian airspace. International Journal of Human Factors Modelling and Simulation, 6(2-3), 103-118.

Santos, M. C. J., Magramo Jr, C. S., Oguan Jr, F., \& Paat, J. (2014). Establishing the relationship between general self-efficacy and subjective well-being among college students. Asian journal of management sciences \& education, 3(1), 1-12.

Slemp, G. R., \& Vella-Brodrick, D. A. (2013). Optimising Employee Mental Health: The Relationship Between Intrinsic Need Satisfaction, Job Crafting, and Employee WellBeing. Journal of Happiness Studies, 1-21.

Sonnentag, S. (2015). Dynamics of well-being. Annu. Rev. Organ. Psychol. Organ. Behav., 2(1), 261-293.

Souza, L. A. S. D., Torres, A. R. R., Barbosa, G. A., Lima, T. J. S. D., \& Souza, L. E. C. D. (2014). Self-efficacy as a mediator of the relationship between subjective well-being and general health of military cadets. Cadernos de saude publica, 30, 2309-2319.

Soysa, C. K., \& Wilcomb, C. J. (2015). Mindfulness, self-compassion, self-efficacy, and gender as predictors of depression, anxiety, stress, and well-being. Mindfulness, 6(2), 217-226.

Stajkovic, A. D., \& Luthans, F. (1998). Self-efficacy and work-related performance: A metaanalysis. Psychological bulletin, 124(2), 240.

Teperi, A.-M., Leppänen, A., \& Norros, L. (2015). Application of new human factors tool in an air traffic management organization. Safety Science, 73, 23-33.

Tobaruela, G., Schuster, W., Majumdar, A., Ochieng, W. Y., Martinez, L., \& Hendrickx, P. (2014). A method to estimate air traffic controller mental workload based on traffic clearances. Journal of Air Transport Management, 39, 59-71.

Tomic, I., \& Liu, J. (2017). Strategies to overcome fatigue in air traffic control based on stress management. Int. J. Eng. Sci., 6(4), 48-57.

Warr, P. (2011). Work, happiness, and unhappiness. Psychology Press.

Wang, H., Hall, N. C., \& Rahimi, S. (2015). Self-efficacy and causal attributions in teachers: Effects on burnout, job satisfaction, illness, and quitting intentions. Teaching and Teacher Education, 47, 120-130.

Wang, J., \& Wang, Y. (2016). The Impact of Character Strengths on Employee Well-Being: The Mediating Effect of Work-Family Relationship, 10(5), 1504-1512.

Xanthopoulou, D., Bakker, A. B., Demerouti, E., \& Schaufeli, W. B. (2009). Reciprocal relationships between job resources, personal resources, and work engagement. Journal of Vocational Behavior, 74(3), 235-244.

Yang, Q., \& Dattel, A. R. (2017). Task Complexity and Time Pressure Affect Air Traffic Controller's Performance and Workload. In 19th International Symposium on Aviation Psychology (p. 359). 
Youssef-Morgan, C. M., \& Luthans, F. (2015). Psychological capital and well-being. Stress and Health, 31(3), 180-188.

Yap, S. T., \& Baharudin, R. (2016). The relationship between adolescents' perceived parental involvement, self-efficacy beliefs, and subjective well-being: A multiple mediator model. Social Indicators Research, 126(1), 257-278.

Zakaria, M., Abdulatiff, N. K., \& Ali, N. (2014). The role of wellbeing on performance in services sector. Procedia-Social and Behavioral Sciences, 164, 358-365. 